\title{
Deodorisasi Sludge Limbah Industri Makanan untuk Pakan Maggot BSF (Black Soldier Fly) dengan Teknik Biosorpsi
}

\section{Deodorization of Food Industrial Sludge for BSF (Black Soldier Fly) Maggot Feed using Biosorption Technique}

\author{
SUSI SULISTIA ${ }^{1,2^{\star}}$, CHARLENA $^{1}$, DAN HANIES AMBARSARI ${ }^{2}$ \\ ${ }^{1}$ Program Studi Kimia, Departemen Kimia, IPB University \\ ${ }^{2}$ Pusat Teknologi Lingkungan, Badan Pengkajian dan Penerapan Teknologi \\ Email: susi.sulistia@apps.ipb.ac.id
}

\begin{abstract}
Organic waste from food and beverage can be degraded by microbes. The sludge from food industries still contains nutrition such as carbohydrates, proteins, and fats. One attempt to process and utilize the sludge is to reuse it as the growth medium for Black Soldier Fly (BSF) maggot, which is known to have high nutritional value for fish or livestock feed. This research used ice cream industrial sludge as maggot feed. The problem of using the ice cream industrial sludge for maggot feed is the odour that pollutes the environment. Biosorption is a technique for deodorizing waste sludge using organic materials. This research was conducted to obtain the most effective ratio of biosorbents from fermented manure (PKN), compost $(K)$, and calcium carbonate animal shells $(\mathrm{Ca})$ to remove odours by reducing $\mathrm{N}$-ammonia and sulfide in ice cream industrial sludge using biosorption techniques. The effect of biosorbent used for BSF (Black Soldier Fly) maggot feed on maggot growth was also observed. The most effective biosorbent composition in reducing odor, $\mathrm{N}$-ammonia, and sulfide of the sludge was K:Ca:Sludge (1:1:3) with adsorption time of 48 hours and the percentage reduction of $85.0 \%$. However, the number and size of maggot with PKN:K:Sludge (1:1:3) growth media were higher than K:Ca:Sludge (1:1:3). The ratio of PKN:K:Sludge (1:1:3) was proven to increase maggots' growth to provide benefits for farmers in increasing maggot production both in number and size.
\end{abstract}

Keywords: Black Soldier Fly maggot, biosorbent, biosorption, organic waste, waste deodorization

\begin{abstract}
ABSTRAK
Limbah organik dari industri makanan dan minuman dapat didegradasi oleh mikroba. Sludge dari limbah industri makanan masih mengandung bahan-bahan nutrisi seperti karbohidrat, protein, dan lemak. Salah satu usaha untuk mengolah dan memanfaatkan sludge tersebut adalah dengan menggunakannya kembali sebagai media pertumbuhan maggot Black Soldier Fly (BSF) yang diketahui sangat tinggi kandungan nutrisinya untuk bahan pakan ikan atau ternak. Penelitian ini menggunakan limbah organik dari industri es krim sebagai pakan maggot. Masalah yang ditimbulkan dari pemanfaatan limbah sludge industri es krim untuk pakan maggot adalah bau yang mengganggu dan mencemari lingkungan. Biosorpsi merupakan salah satu cara untuk menghilangkan bau (deodorisasi) pada limbah sludge. Penelitian ini bertujuan untuk mendapatkan rasio biosorben pupuk kandang fermentasi (PKN), kompos (K) dan kalsium karbonat dari cangkang hewan $(\mathrm{Ca})$ yang paling efektif dalam menghilangkan bau dengan menurunkan $\mathrm{N}$-amonia dan sulfida pada limbah sludge industri es krim melalui teknik biosorpsi. Pengaruh biosorben yang digunakan untuk pakan maggot BSF juga diamati terhadap pertumbuhan maggot. Rasio K:Ca:Sludge (1:1:3) dengan waktu adsorpsi 48 jam merupakan rasio yang lebih efektif untuk menurunkan bau, $\mathrm{N}$-amonia, dan sulfida pada sludge dengan presentase penurunan $85,0 \%$. Akan tetapi, jumlah dan ukuran maggot hasil panen dengan media pertumbuhan PKN:K:Sludge (1:1:3) lebih besar dibandingkan dengan K:Ca:Sludge (1:1:3). Rasio PKN:K:Sludge (1:1:3) terbukti dapat meningkatkan pertumbuhan maggot sehingga memberi manfaat bagi peternak dalam meningkatkan produksi maggot baik secara jumlah dan ukurannya.
\end{abstract}

Kata kunci: maggot Black Soldier Fly, biosorben, biosorpsi, limbah organik, deodorisasi limbah 


\section{PENDAHULUAN}

\subsection{Latar Belakang}

Limbah organik merupakan limbah yang masih dapat didegradasi atau diuraikan oleh mikroba. Salah satu industri yang banyak menghasilkan limbah organik adalah industri makanan atau minuman. Sludge/lumpur hasil unit pengolahan air limbah (IPAL) merupakan jenis limbah organik yang lazimnya dikirim ke pembuangan akhir sebagai limbah bahan berbahaya dan beracun (limbah B3). Pemerintah melalui Peraturan Pemerintah Nomor 101 Tahun 2014 mengatur mekanisme pengecualian sludge pada industri tertentu sebagai limbah non-B3, sehingga dapat dijadikan landasan hukum untuk mengolah dan memanfaatkan sludge dari industri makanan atau minuman menjadi sumber daya proses lain yang bernilai ekonomis. Hasil analisa ilmiah menunjukkan bahwa sludge tersebut masih mengandung bahan-bahan nutrisi yang berguna seperti karbohidrat, protein, lemak, dan sebagainya. Salah satu usaha untuk mengolah dan memanfaatkan sludge tersebut adalah dengan menggunakannya kembali sebagai media pertumbuhan larva maggot Black Soldier Fly (BSF) yang diketahui sangat tinggi kandungan nutrisinya untuk bahan pakan ikan atau ternak ${ }^{(1)}$.

Kandungan protein pada larva maggot cukup tinggi, yaitu $44,26 \%$ dengan kandungan lemak mencapai 29,65\%. Nilai asam amino, asam lemak dan mineral yang terkandung di dalam larva juga tidak kalah dengan sumber-sumber protein lainnya, sehingga larva BSF merupakan bahan baku ideal yang dapat digunakan sebagai pakan ternak $^{(2)}$. Larva maggot BSF dapat tumbuh dan berkembang subur pada media organik, seperti: kotoran sapi, kotoran babi, kotoran ayam, sampah buah dan limbah organik lainnya. Kemampuan larva BSF hidup dalam berbagai media terkait dengan karakteristiknya yang memiliki toleransi $\mathrm{pH}$ yang luas ${ }^{(3)}$.

Limbah sludge industri makanan dan minuman sangat menjanjikan untuk produksi pakan maggot karena ketersediaan dan kapasitasnya yang cukup besar dan kontinu. Pemanfaatan sludge juga dapat menekan biaya pengolahan limbah oleh pihak industri, membantu lingkungan alam supaya lebih bersih, pemanfaat limbah memperoleh limbah secara murah/gratis, dan menjadikan nilai tambah sebagai bahan pakan ternak.

Salah satu industri makanan yang dapat dimanfaatkan limbah sludge-nya sebagai pakan maggot adalah industri pengolahan susu diantaranya industri es krim. Industri es krim menggunakan bahan baku susu sehingga limbah sludge-nya mengandung protein, karbohidrat dan lemak yang dapat menjadi sumber nutrisi untuk maggot. Masalah yang ditimbulkan dari pemanfaatan limbah sludge industri es krim untuk pakan maggot adalah bau yang mengganggu dan mencemari lingkungan ${ }^{(1)}$. Bau yang dihasilkan oleh limbah pada umumnya berupa gas hasil penguraian zat organik yang terkandung dalam limbah, seperti hidrogen sulfida $\left(\mathrm{H}_{2} \mathrm{~S}\right)^{(4)}$. Penyebab bau lainnya adalah amonia. Bahan-bahan yang mengandung protein dan nitrogen organik dengan bantuan bakteri akan mengalami penguraian menjadi amonia(5).

Adsorpsi diketahui merupakan metode yang efisien untuk menghilangkan warna, bau, minyak, dan organik dari limbah ${ }^{(6)}$. Adsorpsi dengan bantuan biomaterial/bahan biologis/bahan alami disebut biosorpsi. Material biologis yang dapat digunakan dalam proses biosorpsi disebut biosorben. Salah satu biosorben yang dapat digunakan dalam biosorpsi adalah kompos. Kemampuan kompos sebagai biosorben diantaranya diaplikasikan sebagai medium biofilter. Penggunaaan kompos dengan karakteristik kandungan organik, C/N rasio, dan kandungan nutrien yang rendah serta persen agregat halus yang lebih tinggi dapat meningkatkan penyisihan organik dan nutrien melalui mekanisme adsorpsi dan degradasi biologis ${ }^{(7)}$. Persentase penyisihan terbesar terdapat pada reaktor uji dengan media kompos setengah matang dengan pemaparan 8 jam pada variasi intermittent $1: 5$, yaitu COD $87,32 \%$, amonium $67,68 \%$, dan fosfat $87,36 \%{ }^{(7)}$. Kompos juga dapat digunakan sebagai medium biofilter dalam mereduksi gas $\mathrm{N}_{2} \mathrm{O}$ dengan efisiensi reduksi setelah 6 jam mencapai $68,37 \%$. Proses biofiltrasi gas $\mathrm{N}_{2} \mathrm{O}$ dalam kolom biofilter dengan medium kompos dapat dimodelkan dengan baik oleh persamaan adsorpsi isotermis Langmuir ${ }^{(8)}$.

Bahan lain yang berpotensi sebagai biosorben adalah kalsium karbonat $\left(\mathrm{CaCO}_{3}\right)$ dari cangkang hewan. Dalam penelitianpenelitian sebelumnya, kalsium karbonat telah digunakan dalam proses adsorpsi diantaranya untuk adsorpsi fosfat pada air dengan kapasitas maksimum adsorpsi $39 \mathrm{mg} \mathrm{P}-\mathrm{PO}_{4} / \mathrm{g}^{(9)}$. Proses defluorinasi air juga dapat dilakukan melalui pemanfaatan kalsium karbonat dari cangkang hewan dengan rasio $1,67 \mathrm{~kg} \mathrm{CaCO} \mathrm{CO}_{3}$ untuk $2 \mathrm{~L}$ air per hari(10). Selain itu, adsorpsi logam berat dalam air dapat dilakukan dengan penggunaan kalsium karbonat dari cangkang hewan, misalnya kadmium dalam air dapat diadsorpsi dengan sebanyak $73 \%^{(11)}$. Kalsium karbonat dari cangkang hewan juga diketahui dapat digunakan sebagai bahan biosorben diantaranya untuk adsorpsi logam berat $\mathrm{Pb}$ dan 
Cd dengan persentase adsorpsi sebesar $65,99 \%$ dan $93,16 \%{ }^{(12)}$.

Biosorpsi untuk penghilangan bau telah dilakukan pada limbah sludge industri susu dengan kandungan amonia $\left(\mathrm{NH}_{3}-\mathrm{N}\right)$ sebesar 10 $15 \%$ yang diduga menjadi senyawa odoran pada limbah lumpur tersebut. Penghilangan amonia dalam lumpur limbah industri susu tersebut dilakukan dengan cara biosorpsi menggunakan karbon aktif ampas kopi robusta dan kulit pisang. Presentase penurunan $\mathrm{NH}_{3}-\mathrm{N}$ adalah sebesar $32-43 \%{ }^{(13)}$. Biosorpsi dalam penghilangan bau (deodorisasi) limbah sludge industri es krim menggunakan biosorben pupuk kandang fermentasi dan kompos dapat menurunkan bau dari skala 315 menjadi 114 (64\%) dan dari skala 315 menjadi $144(54 \%)^{(1)}$. Persentase penurunan bau pada limbah sludge tersebut masih terlalu rendah dan masih menimbulkan bau yang mencemari lingkungan. Kombinasi antara biosorben alami seperti pupuk kandang fermentasi, kompos dan kalsium karbonat dari cangkang hewan diharapkan lebih efektif dalam meningkatkan efisiensi biosorpsi untuk menurunkan bau pada limbah sludge sehingga dapat digunakan sebagai pakan maggot tanpa mencemari lingkungan.

\subsection{Tujuan Penelitian}

Tujuan penelitian ini adalah untuk mendapatkan rasio biosorben yang efektif dalam menghilangkan bau dengan menurunkan $\mathrm{N}$ amonia dan sulfida pada limbah sludge industri es krim melalui teknik biosorpsi, dan mengetahui pengaruh biosorben yang digunakan untuk pakan maggot Black Soldier Fly (BSF) terhadap pertumbuhan maggot tersebut. Hasil penelitian diharapkan dapat memberikan manfaat dalam mengembangkan alternatif pengolahan dan pemanfaatan limbah organik menjadi sumber daya yang bernilai ekonomis dan berkelanjutan ketersediaannya dengan diperolehnya informasi komposisi biosorben efektif dalam proses biosorpsi limbah sludge industri es krim. Komposisi biosorben yang diperoleh juga diharapkan akan meningkatkan pertumbuhan maggot sehingga memberi manfaat bagi peternak maggot dalam meningkatkan produksinya.

\section{BAHAN DAN METODE}

Penelitian dilaksanakan dari bulan Oktober 2020 sampai bulan Mei 2021 di Laboratorium Pusat Teknologi Lingkungan, Badan Pengkajian dan Penerapan Teknologi, Kawasan Puspiptek, Serpong. Penelitian di laboratorium dimulai dengan preparasi sampel sludge limbah es krim, kemudian dilanjutkan dengan analisis proksimat sludge (kadar protein, lemak, karbohidrat, air dan abu), analisis $\mathrm{N}$-amonia dan sulfida, dan terakhir proses adsorpsi bau sludge dengan biosorben pada beberapa variasi rasio dan waktu. Pengukuran $\mathrm{N}$-amonia dan sulfida juga dilakukan untuk sampel yang mengalami penurunan bau yang signifikan.

Pengembangbiakan maggot pada biopond berlokasi di Desa Kebon Kopi, Kecamatan Gunung Sindur, Kabupaten Bogor. Telur maggot yang digunakan dalam penelitian didapatkan dari peternakan maggot BSF di Kabupaten Bogor. Jumlah telur yang dibutuhkan untuk mengolah $100 \mathrm{~kg}$ sampah organik per $\mathrm{m}^{2}$ adalah $6 \mathrm{~g}$ telur. Jadi untuk $1000 \mathrm{~kg}$ sampah per hari akan memerlukan telur sebanyak $60 \mathrm{~g}^{(14)}$. Dalam penelitian ini, digunakan $0,09 \mathrm{~g}$ telur maggot per $1500 \mathrm{~g}$ media pertumbuhan dengan tiga ulangan untuk setiap rasio media pertumbuhan. Pengamatan pertumbuhan maggot dilakukan setelah diberi pakan limbah sludge es krim yang telah mengalami biosorpsi dengan hasil yang paling optimum dilihat dari penurunan bau, $\mathrm{N}$-amonia dan sulfidanya.

\subsection{Bahan dan Alat}

Bahan yang digunakan adalah limbah sludge industri es krim dari kawasan industri Jababeka, biosorben (pupuk kandang fermentasi, kompos dan kalsium karbonat dari cangkang tutut), telur maggot, dan bahan kimia untuk analisa laboratorium (asam sulfat (96\%), kalium sulfat, tembaga (II) sulfat, natrium hidroksida, asam borat, n-heksan, extraction thimble, asam klorida $37 \%$, barium klorida dihidrat, tween 80 , asam asetat glasial, asam fosfat, dan akuades.

Alat yang digunakan pada penelitian ini adalah odor-meter Shinyei OMX-SRM, neraca analitik Sartorius, oven Memmert, soxhlet extractor, spektrofotometer UV-VIS JASCO V530, alat ukur pH, suhu dan kelembaban, dan perangkat analisis Kjeldahl.

\subsection{Metode Analisis Proksimat Sludge}

Analisis proksimat sludge meliputi kadar protein menggunakan metode titrimetri (Kjeldahl), kadar lemak menggunakan metode ekstraksi, kadar air dan abu menggunakan metode gravimetri dan karbohidrat menggunakan metode by difference. Analisis proksimat dilakukan pada sampel awal sebelum proses deodorisasi.

\subsection{Adsorpsi bau sludge dengan biosorben}

Biosorben yang digunakan dalam proses adsorpsi bau adalah pupuk kandang fermentasi (PKN), kompos (K), dan kalsium karbonat dari cangkang tutut (Ca). Rasio 
PKN:sludge (1:3) selama proses adsorpsi 96 jam dapat menurunkan bau limbah sludge sebanyak $85,5 \%{ }^{(1)}$. Oleh karena itu, dalam penelitian ini digunakan rasio 1:3 antara biosorben dan sludge dengan waktu adsorpsi yang lebih singkat yaitu 48 jam. Kombinasi biosorben lain selain PKN, yaitu $\mathrm{K}$ dan $\mathrm{Ca}$ juga digunakan dengan tujuan meningkatkan prosentase penurunan bau pada sludge tersebut. Rasio biosorben yang digunakan ditunjukkan pada Tabel 1.

Tabel 1. Rasio biosorben dan sampel limbah sludge industri es krim

\begin{tabular}{cc}
\hline Adsorben & Rasio \\
\hline $\mathrm{Ca}:$ sludge & $1: 3$ \\
\hline $\mathrm{PKN}: \mathrm{Ca}:$ sludge & $1: 1: 3$ \\
\hline $\mathrm{PKN}: \mathrm{K}:$ sludge & $1: 1: 3$ \\
\hline $\mathrm{K}: \mathrm{Ca}:$ sludge & $1: 1: 3$ \\
\hline $\mathrm{PKN}: \mathrm{K}: \mathrm{Ca}:$ sludge & $1: 1: 1: 3$ \\
\hline
\end{tabular}

Sampel sludge dan biosorben dengan rasio seperti pada Tabel 1 dihomogenkan kemudian diukur bau awalnya. Campuran tersebut kemudian disimpan untuk proses adsorpsi selama 48 jam dengan pengukuran bau setiap 18, 24, dan 48 jam. Kontrol yang digunakan dalam penelitian adalah sampel limbah sludge tanpa biosorben.

\subsection{Pengukuran bau sludge}

Pengukuran bau sludge dilakukan dengan menggunakan alat odor meter pada saat sampel diambil dari unit pengolahan limbah, pada saat akan dicampurkan dengan adsorben dan pada 18, 24, dan 48 jam setelah proses adsorpsi sehingga dapat diketahui penurunan bau nya. Pengukuran bau pada sampel dengan alat odor meter menggunakan prinsip pengukuran tingkat bau dibandingkan dengan udara murni. Penurunan bau dalam satuan persen dihitung berdasarkan Persamaan 1:

$$
\text { Penurunan bau }(\%)=\frac{(\text { bau sampel awal }- \text { bau sampel setelah adsorpsi) }}{\text { bau sampe awal }} * 100
$$

\subsection{Pengukuran N-Amonia}

Sampel halus ditimbang sebanyak $1 \mathrm{~g}$ dan dimasukan ke dalam labu didih destilator, ditambahkan sedikit batu didih, $0,5 \mathrm{~mL}$ parafin cair dan $100 \mathrm{~mL}$ air bebas ion. Blanko adalah $100 \mathrm{~mL}$ air bebas ion ditambah batu didih dan parafin cair. Penampung destilat yaitu $10 \mathrm{~mL}$ asam borat $1 \%$ dalam erlenmeyer $100 \mathrm{~mL}$ yang dibubuhi 3 tetes indikator Conway. Destilasi dilakukan dengan ditambahkan $10 \mathrm{~mL} \mathrm{NaOH}$ $40 \%$. Destilasi selesai bila volume cairan dalam erlenmeyer sudah mencapai sekitar $75 \mathrm{~mL}$. Destilat dititrasi dengan larutan baku $\mathrm{H}_{2} \mathrm{SO}_{4} 0,05$ $\mathrm{N}$, hingga titik akhir (warna larutan berubah dari hijau menjadi merah muda)(15). Pengukuran amonia dilakukan untuk sampel awal sebelum proses adsorpsi dan setiap sampel dengan nilai penurunan bau optimal.

\subsection{Pengukuran Sulfida}

Sampel ditimbang sejumlah $0,250 \mathrm{~g}$ ke dalam labu takar $100 \mathrm{~mL}$, ditambahkan $10 \mathrm{~mL}$ $\mathrm{HCl} 4 \mathrm{~N}$ dengan dispenser dan dipanaskan pada hot plate sampai larut sempurna. Sampel yang telah larut didinginkan dan volume ditepatkan sampai tanda tera $100 \mathrm{~mL}$ dengan air bebas ion. Labu takar ditutup dan dikocok hingga homogen kemudian disaring. Filtrat sejumlah $1 \mathrm{~mL}$ dipipet ke dalam tabung kimia dan ditambahkan $9 \mathrm{~mL}$ air bebas ion (pengenceran 10 kali), dikocok sampai homogen. Larutan deret standar S dan ekstrak sampel yang telah diencerkan 10 kali dipipet masing-masing $1 \mathrm{~mL}$ ke dalam tabung kimia. Larutan standar dan sampel ditambahkan dengan $7 \mathrm{~mL}$ asam campur dan $1 \mathrm{~mL} \mathrm{BaCl}_{2-}$ tween kemudian dikocok sampai homogen. Sampel diukur serapannya dengan spektrofotometer pada panjang gelombang 494 $\mathrm{nm}$ dengan deret standar $S$ sebagai pembanding ${ }^{(15)}$.

\subsection{Pengamatan Pertumbuhan Maggot BSF}

Parameter yang diukur adalah berat maggot per ekor $(\mathrm{g})$ dengan cara menimbang maggot yang sudah dipanen dengan timbangan analitik. Maggot kemudian dikelompokkan berdasarkan ukuran yaitu besar dan kecil kemudian ditimbang lalu diukur panjangnya menggunakan jangka sorong.

\section{HASIL DAN PEMBAHASAN}

\subsection{Analisis Proksimat Sludge}

Analisis proksimat dilakukan untuk mengetahui kadar protein, lemak, karhohidrat, air dan abu dalam sludge sebagai sumber nutrisi yang dibutuhkan untuk pertumbuhan maggot. Hasil analisis laboratorium terhadap parameter proksimat limbah sludge dapat dilihat pada Tabel 2. Nutrisi yang mencukupi dalam media kultur dapat menyebabkan terjadinya peningkatan total produksi maggot dengan cepat, tetapi produksi maggot juga akan mengalami penurunan yang cepat bila kondisi media dan nutrisi tidak mendukung kehidupannya. Dalam siklus daur hidupnya maggot membutuhkan banyak protein, lemak dan karbohidrat pada saat usia 0-14 hari(16). Maggot BSF sebagai salah satu dekomposer terbaik membutuhkan banyak asupan nutrisi untuk bekal saat sudah metamorfosis menjadi lalat. Kekurangan nutrisi pada fase larva akan 
memengaruhi kualitas dan kuantitas telur pada fase lalat ${ }^{(14)}$. Analisis kandungan nutrisi pada sludge dibutuhkan sebelum digunakan sebagai media pertumbuhan maggot. Hasil analisis menunjukkan bahwa limbah sludge es krim memiliki kandungan protein, lemak dan karbohidrat yang dibutuhkan untuk nutrisi pertumbuhan maggot sehingga dapat digunakan sebagai media tumbuh maggot.

Tabel 2. Hasil analisis proksimat limbah sludge es krim

\begin{tabular}{cc}
\hline Parameter & Hasil (\%) \\
\hline Protein & 5,43 \\
\hline Lemak & 10,7 \\
\hline Air & 45,7 \\
\hline Abu & 1,42 \\
\hline Karbohidrat & 36,8 \\
\hline
\end{tabular}

\subsection{Biosorpsi dan Deodorisasi Limbah Sludge Es Krim}

Pengukuran bau menggunakan alat odor meter dilakukan terhadap sampel sludge sebelum dan setelah ditambahkan dengan biosorben. Biosorben yang terdiri dari pupuk kandang fermentasi (PKN), kompos (K) dan kalsium karbonat dari cangkang tutut (Ca) ditambahkan dengan beberapa variasi rasio. Campuran tersebut kemudian disimpan untuk proses adsorpsi selama 48 jam dengan pengukuran bau setiap 18, 24, dan 48 jam. Kontrol yang digunakan dalam penelitian adalah sampel limbah sludge tanpa biosorben. Penurunan bau (\%) pada sampel untuk setiap variasi rasio biosorben dapat dilihat pada Gambar 1.

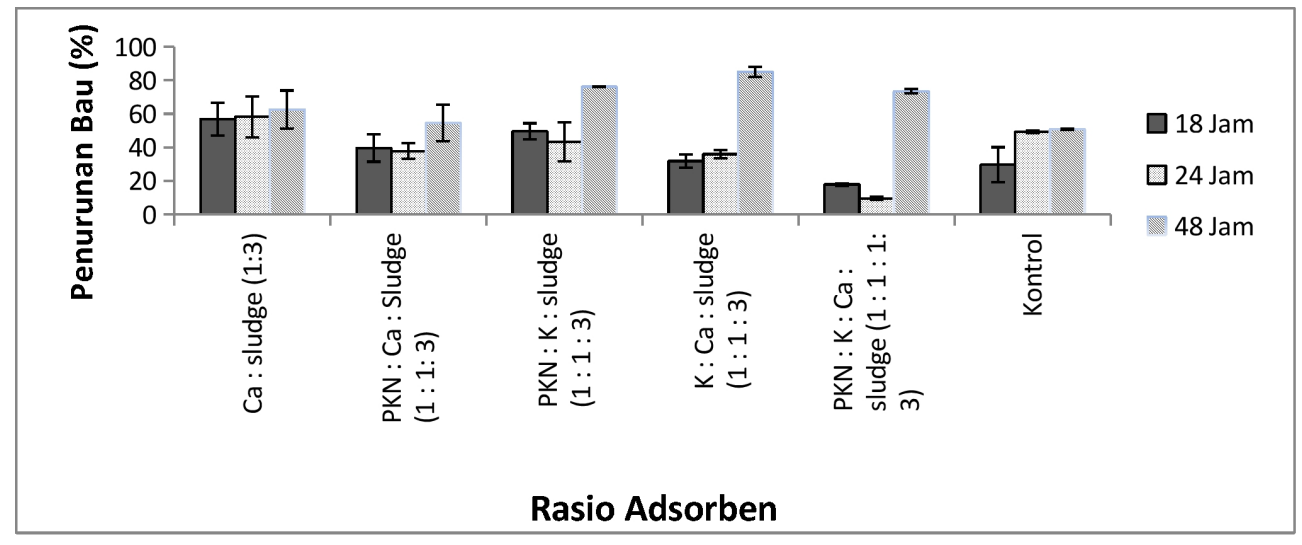

Gambar 1. Penurunan bau (\%) pada sampel sludge setelah proses biosorpsi

Berdasarkan hasil pengukuran bau terhadap sampel sludge setelah dilakukan proses adsorpsi menggunakan variasi biosorben, penurunan bau tertinggi terlihat pada sampel dengan rasio $\mathrm{K}:$ Ca:Sludge (1:1:3) yaitu sebesar $85,0 \%$ dan pada rasio $\mathrm{PKN}: \mathrm{K}:$ Sludge $(1: 1: 3)$ yaitu sebesar $76,1 \%$. Sampel dengan kedua rasio tersebut kemudian dianalisis konsentrasi $\mathrm{N}$-amonia dan sulfida nya untuk diketahui penurunan nilai kedua parameter tersebut setelah proses biosorpsi. Pada penelitian sebelumnya, pupuk kandang (PKN) yang digunakan tanpa tambahan kompos (K) sebagai adsorben dapat menurunkan bau sebanyak $85,5 \%$ tetapi dengan waktu yang lebih lama yaitu 96 jam $^{(1)}$.

\subsection{Analisis N-Amonia dan Sulfida}

Pengukuran konsentrasi $\mathrm{N}$-amonia dilakukan untuk sampel sludge sebelum proses adsorpsi sebagai kontrol dan dua sampel yang mengalami penurunan bau tertinggi yaitu pada $\mathrm{K}: \mathrm{Ca}$ :Sludge (1:1:3) dan PKN:K:Sludge (1:1:3) setelah proses adsorpsi. Grafik konsentrasi N-amonia pada sampel dapat dilihat pada Gambar 2. Penurunan konsentrasi N-Amonia pada sampel PKN:K:Sludge (1:1:3) waktu adsorpsi 48 jam yaitu $69,2 \%$. Pada sampel K:Ca:Sludge (1:1:3) selama waktu adsorpsi 48 jam terjadi penurunan $74,7 \%$. Sedangkan pada kontrol selama waktu kontak 48 jam hanya terjadi penurunan konsentrasi $\mathrm{N}$-amonia sebesar $49,4 \%$. Hal ini menunjukkan bahwa biosorben yang digunakan dapat meningkatkan penurunan $\mathrm{N}$-amonia dengan proses biosorpsi. Salah satu biosorben yaitu kompos banyak digunakan sebagai adsorben dalam biofilter. Model adsorpsi yang sesuai untuk kompos matang adalah model adsorpsi BrunauerEmmett-Teller $(\mathrm{BET})^{(17)}$. Model persamaan adsorpsi BET berdasarkan asumsi adalah bahwa molekul yang diadsorpsi lebih dari satu lapisan tebal pada permukaan media dan proses adsorpsi di setiap permukaan mempunyai komposisi yang heterogen ${ }^{(18)}$. Selain itu proses adsorpsi yang terjadi antara kompos matang dan amonia dalam bentuk gas $\left(\mathrm{NH}_{3}\right)$ merupakan proses adsorpsi secara biologis. Pada media adsorben kompos matang 
dalam biofilter sebagai subtrat untuk mendukung pertumbuhan biofilm mikroba yang dapat membantu dalam mendegradasi senyawa polutan misalnya amonia dalam bentuk gas $\left(\mathrm{NH}_{3}\right)^{(19)}$. Media adsorben kompos dalam mereduksi amonia dengan bentuk gas $\left(\mathrm{NH}_{3}\right)$ menghasilkan efisiensi reduksi sebesar $90 \%$ pada reaktor $\mathrm{R} 1$ yang dicapai pada proses komposting hari ke-40(20).

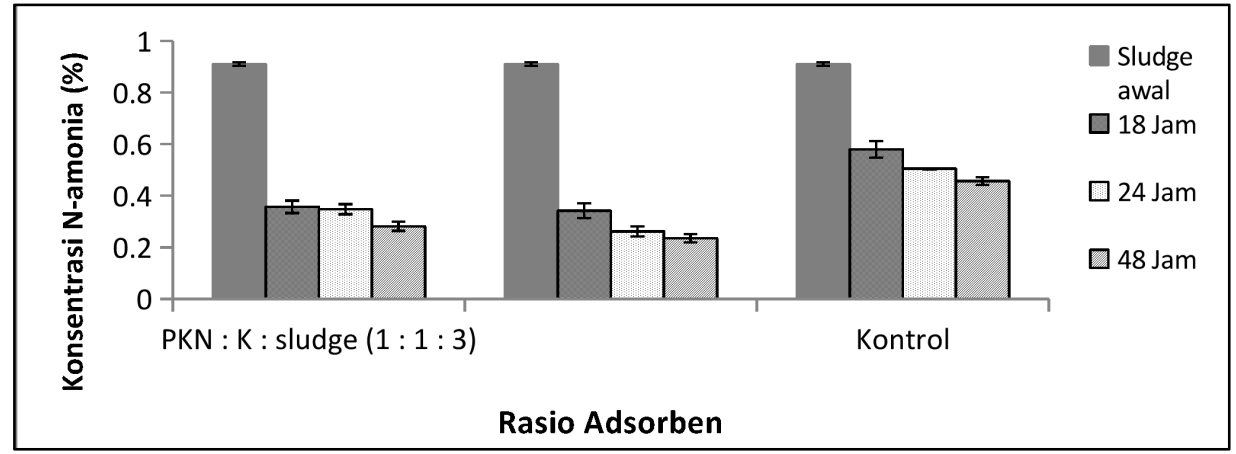

Gambar 2. Konsentrasi N-amonia (\%)

Pengukuran konsentrasi sulfida juga dilakukan untuk sampel sludge sebelum proses adsorpsi sebagai kontrol dan sampel K:Ca:Sludge (1:1:3) dan PKN:K:Sludge (1:1:3) setelah proses adsorpsi. Grafik konsentrasi sulfida pada sampel dapat dilihat pada Gambar 3. Penurunan konsentrasi sulfida tertinggi yaitu sebesar $74,7 \%$ pada sampel K:Ca:Sludge (1:1:3) selama waktu adsorpsi 48 jam. Pada sampel PKN:K:Sludge (1:1:3) adalah pada waktu adsorpsi 48 jam terjadi penurunan konsentrasi sulfida $73,0 \%$, sedangkan pada kontrol selama waktu kontak 48 jam terjadi penurunan konsentrasi sulfida sebesar 12,4\%. Konsentrasi $\mathrm{N}$-amonia dan sulfida yang turun setelah dilakukan proses adsorpsi dengan variasi biosorben pupuk kandang, kompos dan kalsium karbonat dari cangkang tutut berkorelasi dengan turunnya bau sampel setelah proses tersebut. Hal ini menunjukkan bahwa $\mathrm{N}$-amonia dan sulfida merupakan penyebab bau pada sludge limbah. Bau dapat berupa senyawa tunggal maupun berupa gabungan. Bau yang berupa senyawa tunggal seperti hidrogen sulfida $\left(\mathrm{H}_{2} \mathrm{~S}\right)$ dan amonia $\left(\mathrm{NH}_{3}\right)$. Untuk bau yang berupa senyawa gabungan berbagai senyawa, merupakan gabungan kompleks beberapa senyawa(21). Biosorben yang digunakan dalam penelitian dapat meningkatkan penurunan bau, $\mathrm{N}$-amonia dan sulfida dalam sampel sludge dibandingkan dengan sampel kontrol tanpa proses biosorpsi.

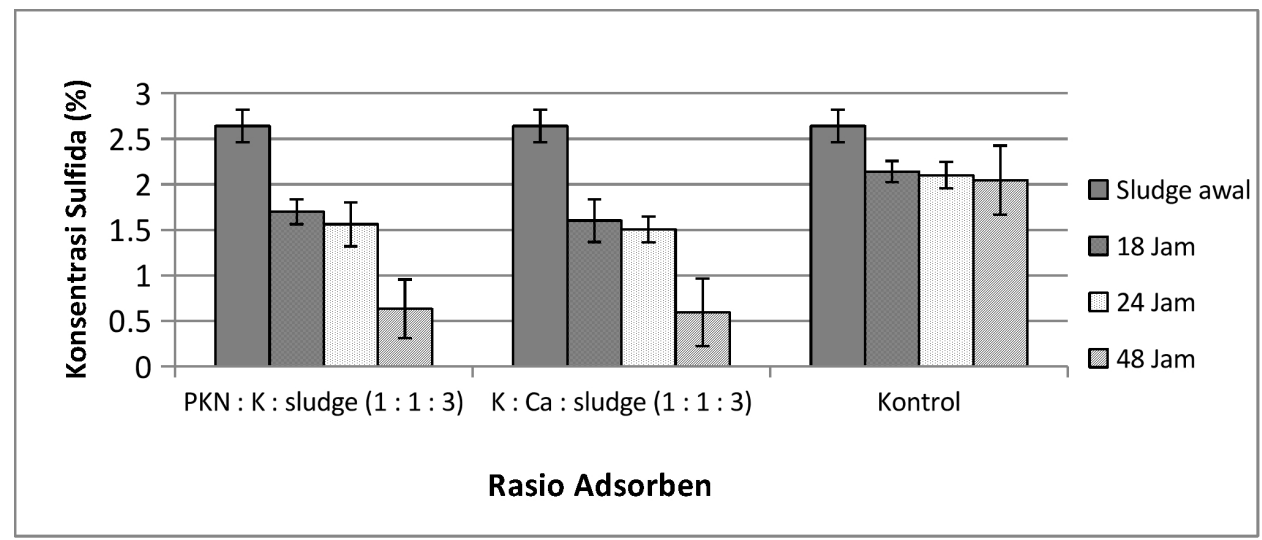

Gambar 3. Konsentrasi Sulfida (\%)

\subsection{Pengukuran pH, Suhu, dan Kelembaban Media Pertumbuhan Maggot}

Pengukuran $\mathrm{pH}$, suhu, dan kelembaban dilakukan pada media pertumbuhan maggot. Media pertumbuhan yang digunakan adalah sampel K:Ca:Sludge (1:1:3) dan PKN:K:Sludge $(1: 1: 3)$ setelah proses adsorpsi 48 jam, serta sampel sludge tanpa penambahan biosorben sebagai kontrol. Pengukuran parameterparameter tersebut dilakukan untuk mengetahui pengaruhnya terhadap pertumbuhan maggot. Hasil pengukuran $\mathrm{pH}$, suhu, dan kelembaban media pertumbuhan dapat dilihat pada Tabel 3 . 
Tabel 3. Pengukuran $\mathrm{pH}$, suhu, dan kelembaban media pertumbuhan maggot

\begin{tabular}{ccccccc}
\hline \multirow{2}{*}{ Media pertumbuhan } & \multicolumn{3}{c}{ Awal } & \multicolumn{3}{c}{ Setelah Panen } \\
\cline { 2 - 7 } & $\mathbf{p H}$ & $\begin{array}{c}\text { Suhu } \\
\left({ }^{\circ} \mathbf{C}\right)\end{array}$ & $\begin{array}{c}\text { Kelembaban } \\
(\%)\end{array}$ & $\begin{array}{c}\text { PH } \\
\text { (\%) }\end{array}$ & $\begin{array}{c}\text { Kelembaban } \\
(\%)\end{array}$ \\
\hline PKN:K:Sludge $(1: 1: 3)$ & 7,5 & 26 & 15 & 7,5 & 25 & 15 \\
\hline K:Ca:Sludge $(1: 1: 3)$ & 8,0 & 26 & 15 & 8,0 & 25 & 10 \\
\hline Kontrol & 6,5 & 25 & 20 & 7,0 & 25 & 20 \\
\hline
\end{tabular}

Kelembaban media K:Ca:Sludge adalah yang paling rendah diantara ketiga media yang digunakan untuk pertumbuhan maggot. Hal ini yang menyebabkan media tersebut lebih kering dan memberi pengaruh terhadap pertumbuhan maggot yang menjadi agak terhambat karena kurangnya kadar air dalam media tersebut.

\subsection{Pertumbuhan Maggot BSF}

Pengamatan pertumbuhan maggot dilakukan untuk mengetahui kemampuan tumbuh maggot pada sampel yang telah mengalami proses deodorisasi dengan cara biosorpsi. Proses pengamatan pertumbuhan maggot dimulai dengan penetasan telur maggot di dalam media pertumbuhannya. Media pertumbuhan yang digunakan adalah sampel $\mathrm{K}: \mathrm{Ca}:$ Sludge (1:1:3) dan PKN:K:Sludge (1:1:3) setelah proses adsorpsi 48 jam, serta sampel sludge tanpa penambahan biosorben sebagai kontrol.

Pengamatan maggot dilakukan setelah 14 hari dengan parameter berat dan ukuran maggot pada setiap biopond. Maggot setelah dipanen dan dipisahkan dari media pertumbuhannya dapat dilihat pada Gambar 4a, 4b, dan 4c. Hasil pengamatan pertumbuhan maggot dapat dilihat pada Tabel 4 .

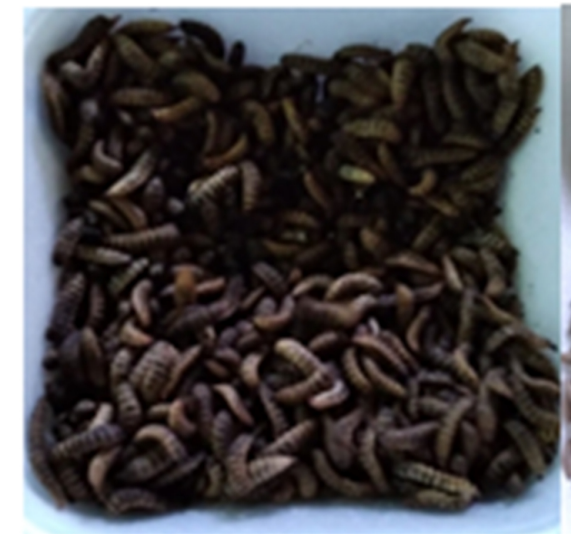

(a)

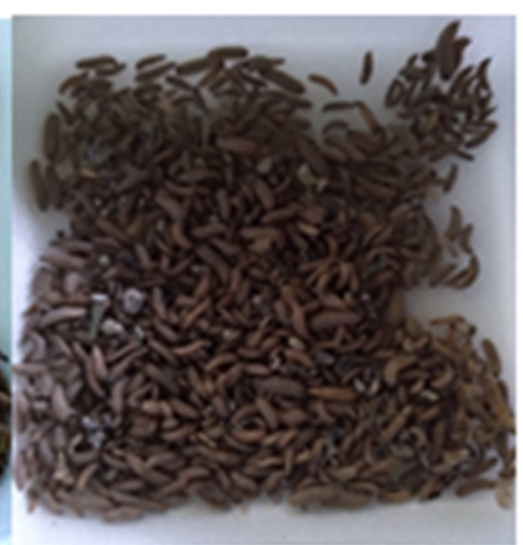

(b)

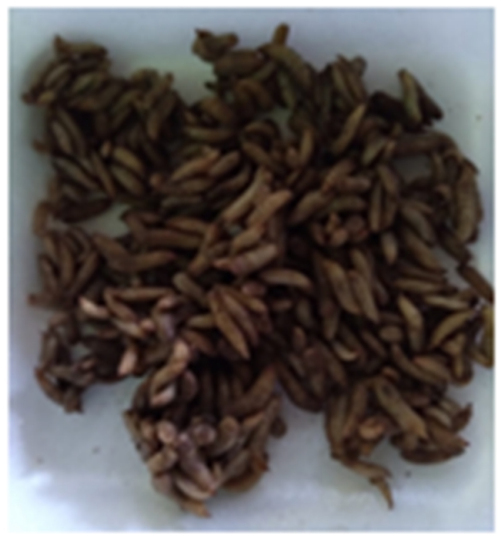

(c)

Gambar 4(a). Maggot dengan media pertumbuhan PKN:K:Sludge (1:1:3), (b) Maggot dengan media pertumbuhan K:Ca:Sludge (1:1:3), (c) Maggot dengan media pertumbuhan sludge tanpa biosorben

Tabel 4. Hasil pengamatan pertumbuhan maggot

\begin{tabular}{cccc}
\hline \multirow{2}{*}{ Parameter } & \multicolumn{3}{c}{ Media tumbuh } \\
\cline { 2 - 4 } & PKN:K:Sludge (1:1:3) & K:Ca:Sludge (1:1:3) & Sludge \\
\hline Berat maggot $(\mathrm{g})$ & 146 & 22 & 72 \\
\hline Ukuran maggot $(\mathrm{cm})$ & $0,6-1,4$ & $0,3-0,7$ & $0,5-1,1$ \\
\hline $\begin{array}{c}\text { Berat maggot }(\text { rata- } \\
\text { rata per ekor) }(\mathrm{g})\end{array}$ & 0,09 & 0,01 & 0,04 \\
\hline Warna maggot & abu kehitaman & coklat muda & coklat muda \\
\hline
\end{tabular}

Berdasarkan hasil pengamatan, biosorben yang paling baik untuk mendapatkan jumlah maggot terbanyak adalah pupuk kandang (PKN) dan kompos $(\mathrm{K})$ dengan rasio $1: 1: 3$ (PKN:K:Sludge). Jumlah maggot yang diperoleh lebih banyak daripada media pertumbuhan sludge saja tanpa adanya biosorben. Media pertumbuhan $\mathrm{K}: \mathrm{Ca}$ Sludge dapat menumbuhkan maggot tetapi dengan jumlah yang lebih sedikit dan ukuran yang relatif lebih kecil dibandingkan dengan kontrol dan PKN:K:Sludge (1:1:3) . Hal ini dapat 
disebabkan oleh adanya kalsium karbonat yang menyebabkan kondisi media menjadi lebih kering dan kelembaban yang lebih rendah (10\%) dibandingkan dua media lainnya, sehingga pertumbuhan maggot menjadi terhambat. Maggot mempunyai mulut yang halus dan tidak memiliki gigi. Karena itu sampah organik yang diolah harus lembut, dan memiliki kandungan air lebih dari $60 \%{ }^{(14)}$. Penelitian lain menyebutkan bahwa larva Black Soldier Fly hanya dapat tumbuh pada media dengan kadar air yang rendah ${ }^{(22)}$, sehingga kadar air yang terlalu tinggi hanya akan menghambat perkembangbiakan larva Black Sodier Fly. Kadar air media yang tinggi merupakan penyebab sulitnya larva mereduksi pakan ${ }^{(23)}$. Ketika proses reproduksi lalat terjadi, lalat jenis ini akan menyukai media tumbuh yang khas dan ketika dia menyukai aroma tersebut maka lalat tersebut mau hidup dan berkembang di media tersebut ${ }^{(24)}$. Lalat ini sangat cepat pertumbuhannya dan mudah tumbuh di limbah organik seperti kotoran unggas. Ketika maggot lalat Black Soldier Fly matang, dibutuhkan waktu 3-4 hari untuk dijadikan pakan yang akan melalui proses pengeringan dan penggilingan untuk dijadikan bahan pakan ${ }^{(25)}$.

Biosorben PKN dan K relatif lebih murah dan mudah diperoleh dibandingkan dengan $\mathrm{Ca}$ dari cangkang hewan. PKN dan $\mathrm{K}$ yang dijual di pasaran dapat digunakan langsung sebagai biosorben, sedangkan $\mathrm{Ca}$ dari cangkang hewan memerlukan beberapa tahapan proses diantaranya pengeringan, penghalusan dan pengayakan sebelum digunakan sebagai biosorben. Oleh karena itu, PKN dan $\mathrm{K}$ yang dikombinasikan dengan limbah sludge es krim lebih berpotensi digunakan sebagai media pertumbuhan maggot BSF.

\section{KESIMPULAN}

Rasio K:Ca:Sludge (1:1:3) dengan waktu adsorpsi 48 jam lebih efektif untuk menurunkan bau, $\mathrm{N}$-amonia, dan sulfida pada sludge dengan persentase penurunan $85,0 \%, 74,7 \%$, dan $74,7 \%$, dibandingkan dengan PKN:K:Sludge (1:1:3) waktu adsorpsi 48 jam yang dapat menurunkan $76,1 \%$ bau, 69,2\% $\mathrm{N}$-amonia, dan $73,0 \%$ sulfida pada sludge. Akan tetapi, jumlah dan ukuran maggot hasil panen dengan media pertumbuhan PKN:K:Sludge (1:1:3) lebih besar dibandingkan dengan K:Ca:Sludge (1:1:3). Biosorben PKN dan $\mathrm{K}$ dengan rasio PKN:K:Sludge (1:1:3) terbukti dapat meningkatkan pertumbuhan maggot secara jumlah dan ukurannya.

\section{PERSANTUNAN}

Penulis menyampaikan terima kasih kepada Saintek - Badan Riset dan Inovasi Nasional sebagai pemberi beasiswa, Program Pengembangan Teknologi Industri (PPTI) Kemenristekdikti, dan seluruh staf laboratorium Pusat Teknologi Lingkungan - BPPT yang telah membantu dalam pelaksanaan penelitian ini. Semua penulis makalah ini adalah sebagai kontributor utama publikasi.

\section{DAFTAR PUSTAKA}

1. Ambarsari, H. (2019). Pengembangan dan penerapan teknologi pengolahan limbah organik industri menjadi pakan maggot BSF (Black Soldier Fly) untuk mendukung program ketahanan pangan. Laporan Akhir Program Pengembangan Teknologi Industri 2019.

2. Fahmi, M. R., Hem, S., \& Subamia, I. W. (2007). Potensi maggot sebagai salah satu sumber protein pakan ikan. Dalam: Dukungan Teknologi untuk Meningkatkan Produk Pangan Hewan dalam Rangka Pemenuhan Gizi Masyarakat. Prosiding Seminar Nasional Hari Pangan Sedunia XXVII. Bogor (Indonesia): Puslitbangnak. hlm. 125-130.

3. Mangunwardoyo, W., Aulia, Hem, S. (2011). Penggunaan bungkil inti kelapa sawit hasil biokonversi sebagai substrat pertumbuhan larva Hermetia Illucens L (maggot). Biota. 16:166-172.

4. Puji \& Rahmi, N. (2009). Pengolahan Limbah Cair Domestik Menggunakan Lumpur Aktif Proses Anaerob. [Tesis]. Universitas Diponegoro, Fakultas Teknik. Semarang.

5. Zulkifli, E. (2003). Kandungan zat hara dalam air poros dan air permukaan Padanglamun Bintan Timur Riau. J. Natur Indonesia, 5(2), 139-144.

6. Murti, R. S., Purwanti, C. M. H., Suyatni. (2013). Adsorpsi amonia dari limbah cair industri penyamakan kulit menggunakan abu terbang bagas. Majalah Kulit, Karet, dan Plastik. 29(2), 85-90.

7. Pirade, F. (2017). Uji kemampuan kompos sebagai media biofilter untuk menurunkan COD, amonium, fosfat pada air limbah domestik. Institut Teknologi Sepuluh Nopember.

8. Utami, T. S. (2011). Pengembangan Biofilter Sebagai Alternatif Pereduksi Emisi Nitrogen Oksida Melalui Pemanfaatan Kompos Sebagai Medium Filter. [Disertasi]. Program Studi Teknik Kimia Fakultas Teknik Universitas Indonesia.

9. Santos, A. F., Arim, A. L., Lopes, D.V., Gando Ferreira, L. M., Quina, M. J. (2019). 
Recovery of phosphate from aqueous solutions using calcined eggshell as an ecofriendly adsorbent. Journal of Environmental Management 238, 451-459. https://doi.org/10.1016/j.jenvman.2019.03.015.

10. Wong, E. Y., Stenstrom, M. K. (2017). Onsite defluoridation system for drinking water treatment using calcium carbonate. Journal of Environmental Management, 15.http://dx.doi.org/10.1016/j.jenvman.2017.06. 060.

11. Tizo, M. S., Blanco, L. A. V., Cagas, A. C. Q., Dela Cruz, B. R. B., Encoy, J. C., Gunting, J. V., Arazo, R. O., Mabayo, V. I. F. (2018). Efficiency of calcium carbonate from eggshells as an adsorbent for cadmium removal in aqueous solution, Sustainable Environment Research. doi: https://doi.org/10.1016/j.serj.2018.09.002.

12. Maslahat, M., Taufiq, A., Subagja P.W. (2015). Pemanfaatan limbah cangkang telur sebagai biosorben untuk adsorpsi logam $\mathrm{Pb}$ dan $\mathrm{Cd}$. Jurnal Sains Natural Universitas Nusa Bangsa. 5(1), $92-100$.

13. Chasanah, S. D. (2019). Adsorpsi amonia Pada Lumpur Limbah Industri Susu dengan Menggunakan Ampas Kopi dan Kulit Pisang.[skripsi]. Universitas Bakrie.

14. Puspita, H., Prasetya, A., \& Mulyadi A. D. (2020) Black Soldier Fly, Panduan Pengolahan Sampah Organik Sejenis Rumah Tangga Berbasis Biokonversi, Direktorat Pengelolaan Sampah, Limbah, dan B3. Kementrian Lingkungan Hidup dan Kehutanan.

15. Eviati \& Sulaeman. (2009). Analisis kimia tanah, tanaman, air, dan pupuk, Petunjuk Teknis Edisi 2. Balai Penelitian Tanah. Bogor.

16. Cicilia, A. P., Susila, N. (2018). Potensi ampas tahu terhadap produksi maggot sebagai sumber protein pakan ikan. Anterior Jurnal, 18(1),40 - 47.

17. Rahmawati, T., Ratnawati, R., Trihadiningrum, Y. (2013). Reduksi Emisi Amonia Menggunakan Limbah Padat Rumah Potong Hewan dengan Sistem Five-Stage Sequencing Batch Reactor. Fakultas Teknik
Sipil dan Perencanaan. Institut Sepuluh Nopember. Surabaya.

18. Sugito \& Ratnawati, R. (2018). Aerobic Composting of Rumen Content Waste and Rice Straw at Different C/N Ratios, The 1st International Conference on Innovation in Research. Bali, Indonesia. [Prosiding].

19. Ratnawati, R., \& Trihadiningrum, Y. (2014). Pengolahan Limbah Padat Rumah Potong Hewan dengan Proses Pengomposan Limbah Padat Rumah Potong Hewan dengan Metode A2O dan Five-Stage Sequencing Batch, Seminar Nasional Waste Management II, Surabaya 4 Februari 2014, p. 64-71. [prosiding].

20. Sugito \& Ratnawati, R. (2019). Adsorpsi Emisi Amonia pada Proses Pengomposan Limbah Padat Rumah Potong Hewan menggunakan Media Kompos Matang, SNHRP-II : Seminar Nasional Hasil Riset dan Pengabdian, Ke-II, 2019, http://snhrp.unipasby.ac.id

21. Yowono, A.,S. (2008). Kuantifikasi bau dan polusi bau di Indonesia. Jurnal Purifikasi, 9(2), $175-186$.

22. Tran, G. Gnaedinger, C., Melin, C. (2014). Black soldier Fly Larvae (Hermetia illucens). Feedipedia. Org. Melalui: http://www.feedipedia.org/node.16388.

23. Hakim, A. R. (2017). Produksi Bahan Pakan Ikan dari Larva Hermetia Illucens Berbasis Limbah Industri Pengolahan Ikan dan Kajian Keekonomiannya. [Tesis]. Universitas Gadjah Mada.

24. Katayane, F.A., Bagau, B., Wolayan, F.R., Imbar, M. R. (2014). Produksi dan kandungan maggot (Hermetia illucens) dengan media tumbuh yang berbeda. Jurnal Zootek. 34, 27-36.

25. Widjastuti, T., Wiradimadja, R., Rusmana, D. (2014). The effect of substitution of fish meal by black soldier fly (hermetia illucens) maggot meal in the diet on production performance of quail (coturnix coturnix japonica). Scientific Papers Series D Animal Science. 57,125 - 129. 